\title{
Potential Development of Bali Cattle in Muna Regency in Efforts to Support National Meat Self-Sufficiency
} Muhammad Amrullah Pagala. ${ }^{1 *}$, Deki Zulkarnain. ${ }^{1}$, Hidayat ${ }^{1}$, La Ode Munadi ${ }^{1}$

${ }^{1}$ Faculty of Animal Science, Halu Oleo University, Kendari, Indonesia

Corresponding email : amrullah.pagala@uho.ac.id

\begin{abstract}
Bali Cattle is one of the native Indonesian cows with high environmental adaptation. The purpose of this study was to determine the potential for the development of Bali cattle in the Muna District. The study was conducted from September to November 2019. A total of 150 farmers were interviewed as primary data. Secondary data were collected from the District, village, and related government offices. In this study, using LQ Capacity, and SWOT Analysis. The results showed that seven sub-districts had the potential to develop Bali cattle and five sub-districts with forage production that could meet the consumption needs of Bali cattle, and the SWOT analysis showed a positive trend in the development of the Bali cattle sector.
\end{abstract}

Keywords : Bali Cow, Location Quotient, Carrying Capacity, SWOT

\section{INTRODUCTION}

Muna Regency as a whole has an area of $\pm 2,057.69$ $\mathrm{Km} 2$ or $\pm 205,769 \mathrm{Ha}$. Bali Cattle in Muna Regency has a population of 56,795. Nugroho (2006). Strategies for developing livestock breeding areas that have developed. Bamualim et al. (2008) added that the development of beef cattle farms was carried out jointly by the government, the community, and the private sector. Statement of Saili et al. (2017) states that beef cattle breeding areas are areas specifically designated for beef cattle activities (Pambudy and Sudardjat, 2000). Improving human resources in animal husbandry can be done through coaching (Hidayati, 2009). Musram Abadi et al. (2019) The results of the KPPTR analysis show that West Muna Regency can accommodate cattle for 2,669 and goats for 3,293. Sumanto and Juarini (2004), the area of animal husbandry development is carried out through a system approach, which is an approach that is functionally integrated and intact. The need for cattle feed per cow is based on the dry matter if the ration is $30 \%$ or $40 \%$ using the assumption of one cow dry material per day 3\% of body weight (Parrakasi, 1999). Santosa (1995) states that one Livestock Unit (ST) is equivalent to one cow weighing $455 \mathrm{~kg}$.

\section{RESEARCH METHOD}

\section{Location, Time, Data and Research Samples}

This research took place for 3 months from September to November 2019 in Muna Regency. The selection of the research area was carried out purposively (deliberately) with the consideration that in Muna District was one of the bases for developing beef cattle farms.

\section{Data collection}

Collecting data using survey methods. The survey method is a method of gathering information from a sample to represent the entire population. This method is considered more appropriate and can 
gather more in-depth information from farmers selected as research respondents. Respondents were given several questions (questionnaire). The data in this study are primary data and secondary data following research needs. Primary data is used to identify the beef cattle breeding business. Meanwhile, secondary data were obtained from literature, BPS, Agriculture, Animal Husbandry and other related institutions.

\section{Population and Research Samples}

The population of this research is all Bali cattle breeders in the Muna district. The sample in this study was 150 Bali cattle breeders spread across several sub-districts in the Muna Regency.

\section{Data analysis}

Data analysis techniques used in this study include:

L / Q Analysis (Location Quotient) Analyzing the potential area of the development of the Bali cattle base in the Muna Regency used L / Q analysis. The L / $\mathrm{Q}$ analysis is used to identify the dominant Bali cattle population area and is still able to be developed with the following formula:

$$
L Q_{k}=\frac{Y_{s k} / Y_{t k}}{Y_{s p} / Y_{t p}}
$$

SWOT analysis is the systematic identification of various factors based on the logic that can maximize strengths (strengths) and opportunities (Opportunities) but simultaneously can minimize weaknesses (Weaknesses) and threats (Threats). SWOT analysis compares the internal factors of strength (Strengths) and weaknesses (Weaknesses) with external factors of opportunity (Opportunities) and threats (Threats) to produce an appropriate analysis (David, 2006 and Rangkuti, 2006).

Carrying capacity. The carrying capacity analysis is done by calculating the capacity of the area based on the availability of feed sources. The basic assumption of calculating the capacity of livestock based on land use is done with the calculation that, on forest land can produce as much as $1 / 10$ times the natural grass of grassland $(0.1 \times 6.178=617.8 \mathrm{~kg} / \mathrm{ha} / \mathrm{yr})$ grassland consists of $70 \%$ grass nature and 30\% Imperata cylindrical rice fields produce natural grass and Imperata cylindrical as much as $30 \%$ of annual harvest from pasture $(3,089 \mathrm{~kg} / \mathrm{ha} /$ year $)$ natural grass production as much as $6,178 \mathrm{bk} / \mathrm{kg} /$ year (Nafiu et al, 2017).

\section{RESULTS AND DISCUSSION}

\section{a. General Description of Muna Regency}

Muna Regency has a land area of $2,057.68 \mathrm{~km}^{2}$ or 207,769 Ha, divided into 22 districts, namely Tongkuno District, South Tongkuno District, Parigi District, Bone District, Marobo District, Kabawo District, Kabangka District, Kontu Kowuna District, Kontunaga District, Watopute Subdistrict, Katobu Subdistrict, Lohia Subdistrict, Duruka Subdistrict, Batalaiworu Subdistrict, Napabalano Subdistrict, Lasalepa Subdistrict, Towea Subdistrict, South Wakorumba Subdistrict, Pasir Putih Subdistrict, Pasir Putih Subdistrict, Pasikolaga Subdistrict, Maligano Subdistrict, and Batukara Subdistrict. The area in each district is presented in Table 1.

Table 1. The area by District in Muna Regency in 2019

\begin{tabular}{llcc}
\hline Sub-district & $\begin{array}{l}\text { Large } \\
\left(\mathrm{Km}^{2}\right)\end{array}$ & Percent(\%) \\
\hline 1 & Tongkuno & 440,98 & 21,43 \\
2 & $\begin{array}{l}\text { Tongkuno } \\
\text { Selatan }\end{array}$ & 57,26 & 2,78 \\
3 & Parigi & 123,76 & 6,01 \\
4 & Bone & 130,09 & 6,32 \\
5 & Marobo & 41,37 & 2,01 \\
6 & Kabawo & 204,94 & 9,96 \\
7 & Kabangka & 97,62 & 4,74
\end{tabular}




\begin{tabular}{|c|c|c|c|}
\hline \multicolumn{2}{|c|}{ Sub-district } & \multirow{2}{*}{$\begin{array}{c}\begin{array}{c}\text { Large } \\
\left(\mathrm{Km}^{2}\right)\end{array} \\
70,56\end{array}$} & \multirow{2}{*}{$\begin{array}{c}\text { Percent(\%) } \\
3,43\end{array}$} \\
\hline 8 & $\begin{array}{l}\text { Kontu } \\
\text { Kowuna }\end{array}$ & & \\
\hline 9 & Kontunaga & 50,88 & 2,47 \\
\hline 10 & Watopute & 100,12 & 4,87 \\
\hline 11 & Katobu & 12,88 & 0,63 \\
\hline 12 & Lohia & 49,81 & 2,42 \\
\hline 13 & Duruka & 11,52 & 0,56 \\
\hline 14 & Batalaiworu & 22,71 & 1,10 \\
\hline 15 & Napabalano & 105,47 & 5,13 \\
\hline 16 & Lasalepa & 107,92 & 5,24 \\
\hline 17 & Towea & 29,02 & 1,41 \\
\hline 18 & $\begin{array}{l}\text { Wakorumba } \\
\text { Selatan }\end{array}$ & 95,00 & 4,62 \\
\hline 19 & Pasir Putih & 89,53 & 4,35 \\
\hline 20 & Pasi Kolaga & 48,77 & 2,37 \\
\hline 21 & Maligano & 98,09 & 4,77 \\
\hline 22 & Batukara & 69,39 & 3,37 \\
\hline & Muna & 2 & 100,00 \\
\hline
\end{tabular}

\begin{tabular}{lll}
\hline Sub-district & $\begin{array}{l}\text { Large } \\
\left(\mathrm{Km}^{2}\right)\end{array}$ & Percent(\%) \\
\hline & 057,69 & \\
\hline
\end{tabular}

Source: Muna Regency in Figures, 2019

Muna Regency is an archipelago located in the Sulawesi region of the southern part of Sulawesi including the northern part of Buton and Muna Islands. In 2017 it was reported that the total area of Muna Regency after the expansion of the new Administration area (West Muna Regency) was \pm 2,057.69 Km2 or 205,769 ha.

\section{b. The population of Bali Cattle in Muna Regency}

Muna Regency is one of the regions in Southeast Sulawesi that has a relatively high population of ruminant animals. Data on the distribution of Bali cattle per district from year to year shows a trend of increasing population. The detailed population of Bali cattle in 2017-2019 in the Muna Regency is presented in Table 2.

Table 2. The population of Bali Cattle in Muna Regency, 2019

\begin{tabular}{clccc}
\hline \multirow{2}{*}{ No } & sub-district & \multicolumn{3}{c}{ Total population } \\
\cline { 3 - 5 } & & $\mathbf{2 0 1 7}$ & $\mathbf{2 0 1 8}$ & $\mathbf{2 0 1 9}$ \\
\hline 1 & Tongkuno & 4.935 & 7.683 & 8.718 \\
2 & Tongkuno Selatan & 1.984 & 2.821 & 3.327 \\
3 & Parigi & 4.869 & 6.744 & 7.839 \\
4 & Bone & 1.483 & 2.586 & 3.057 \\
5 & Marobo & 502 & 895 & 1.112 \\
6 & Kabawo & 2.463 & 3.804 & 3.358 \\
7 & Kabangka & 3.306 & 4.914 & 5.734 \\
8 & Kontukowuna & 926 & 1.731 & 2.074 \\
9 & Kontunaga & 709 & 1.019 & 1.255 \\
10 & Watopute & 2.984 & 3.992 & 4.674 \\
11 & Katobu & 127 & 193 & 305 \\
12 & Lohia & 1.496 & 2.060 & 2.452 \\
13 & Duruka & 224 & 704 & 893 \\
14 & Batalaiworu & 563 & 1.089 & 1.335
\end{tabular}




\begin{tabular}{clccc}
\hline \multirow{2}{*}{ No } & \multirow{2}{*}{ sub-district } & \multicolumn{3}{c}{ Total population } \\
\cline { 3 - 5 } & & $\mathbf{2 0 1 7}$ & $\mathbf{2 0 1 8}$ & $\mathbf{2 0 1 9}$ \\
\hline 15 & Napabalano & 3.943 & 5.038 & 5.827 \\
16 & Lasalepa & 3.722 & 4.936 & 5.709 \\
17 & Towea & 286 & 495 & 652 \\
18 & Wakorumba Selatan & 721 & 1.035 & 1.223 \\
19 & Pasir Putih & 692 & 997 & 1.180 \\
20 & Pasi Kolaga & 902 & 1.378 & 1.418 \\
21 & Maligano & 1.597 & 2.234 & 2.486 \\
22 & Batukara & 217 & 447 & 597 \\
\hline & Muna & & 56.789 & 66.325
\end{tabular}

Source: Muna Regency in Figures, 2019

Table 2 shows that the population of Bali cattle in

\begin{tabular}{llccc}
\hline No & Sub-district & Bali Cow & Horse & Goat \\
\hline 5 & Watopute & 1,08 & 0,00 & 0,72 \\
6 & Napabalano & 1,13 & 1,34 & 0,48 \\
7 & Lasalepa & 1,17 & 0,00 & 0,37 \\
\hline
\end{tabular}

Source: L / Q Analysis Results, 2019. population of Bali cattle is in Tongkuno Subdistrict which reaches 8,718 tails and the smallest population is in Katobu Subdistrict as many as 305 tails.

\section{c. Bali Cattle Development Base Area in Muna Regency}

Bali cattle in Muna Regency is one of the leading commodities in the livestock subsector and is a business that can provide benefits to the addition of community income sources. The determination of Bali cattle as a superior commodity for ruminants is based on the results of the L / Q analysis. Based on the results of the $\mathrm{L} / \mathrm{Q}$ analysis shows that for the development base areas there are in several districts. For more details, presented in Table 3.

Table 3. Results of the L / Q analysis of the Muna Regency livestock base area, 2019.

\begin{tabular}{llccc}
\hline No & Sub-district & Bali Cow & Horse & Goat \\
\hline 1 & Tongkuno & 1,16 & 0,64 & 0,39 \\
2 & Tongkuno & 1,02 & 1,18 & 0,72 \\
& Selatan & & & \\
3 & Parigi & 1,14 & 2,27 & 0,39 \\
4 & Kabangka & 1,00 & 0,67 & 1,00
\end{tabular}

Table 3 shows the results of the L / Q analysis several districts can be used as the base area for the development of Bali cattle in Muna Regency, namely Tongkuno District with an L / Q value of 1.16, South Tongkuno 1.02, Parigi 1.14, Kabangka 1.00, Watopute 1.08, Napabalano 1.13 and Lasalepa 1.17. This is supported by several factors including the significant population, the availability of large enough land, the ease of marketing, the carrying capacity of human resources, the availability of feed sources and agricultural products, and the supporting infrastructure of the Bali cattle business that has been run by the community. Locally for generations.

\section{d. Carrying Capacity}

Calculation of livestock carrying capacity is an analysis used to determine the region's ability to accommodate Bali cattle based on forage production. In Muna Regency, the calculation of carrying capacity is based on three approaches to forage production, namely: Mapping forage production based on land use, forage production based on forage type or botanical composition, and forage production based on agricultural products. The assumption of calculating 
the carrying capacity of livestock (Caring Capacity) based on land use is made by calculating that on forest land can produce as much as $1 / 10$ times natural grass, and grassland consists of $70 \%$ natural grass and $30 \%$ Imperata cylindrical. (Nafiu et al., 2017). Carrying capacity for the area of livestock development base is divided into several sub-districts, including the Districts of Tongkuno, South Tongkuno, Parigi, Kabangka, Watopute, Napabalano, and Lasalepa Districts. For more details, it is presented in Table 4.

Table 4. Carrying Capacity of Livestock in Muna Regency, 2019.

\begin{tabular}{lcccccc}
\hline Sub-district & $\begin{array}{c}\text { KT Forage } \\
\text { Kype } \\
\text { Use } \\
\text { (Ha) }\end{array}$ & $\begin{array}{c}\text { KT } \\
\text { Production } \\
\text { (Ton/Year) }\end{array}$ & $\begin{array}{c}\text { KT Total } \\
\text { al } \\
\text { Inclusion } \\
\text { Results } \\
\text { (Ton/Year) } \\
\text { (Ton/Year) }\end{array}$ & $\begin{array}{c}\text { Existing } \\
\text { Population } \\
\text { (Cow) }\end{array}$ & $\begin{array}{c}\text { Total carrying } \\
\text { capacity of } \\
\text { cattle (Cow) }\end{array}$ \\
\hline Tongkuno & 3.210 & 3.302 & 2.248 & 8.760 & 8.718 & \\
Tong. Selatan & 1.362 & 1.408 & 428 & 3.198 & 3.327 & 0 \\
Parigi & 5.590 & 5.652 & 1.613 & 12.855 & 7.839 & 5.016 \\
Kabangka & 2.464 & 2.526 & 2.942 & 7.932 & 5.734 & 2.198 \\
Watopute & 2.000 & 2.065 & 1.526 & 5.591 & 4.674 & 917 \\
Napabalano & 2.373 & 2.481 & 1.179 & 6.033 & 5.827 & 206 \\
Lasalepa & 1.200 & 1.293 & 451 & 2.944 & 5.709 & 0 \\
\hline
\end{tabular}

Source: Results of carrying capacity analysis, 2019.

Table 4 shows that Muna Regency is still dominated by regions that have a low carrying capacity. The subdistrict area consists of Tongkuno District has a carrying capacity of 42 tails, South Tongkuno 0 tails, and Lasalepa District 0 tails. If reviewed based on the potential of existing land or under grazing. For this reason, as the first step for breeders in the three subdistricts, they planted forage types to overcome the problem of food shortages. This is in line with the results of the study of Musram et al. (2019) that breeders in West Muna Regency cultivated elephant grass around the yard, around the fields, and around sometimes farms.

\section{e. SWOT Analysis of Internal and External Environmental Factors}

Beef cattle business conditions are determined by a combination of internal and external factors, both of which must be considered in the SWOT analysis. SWOT analysis is useful in mapping the position of the livestock business and the programs that apply in the identification of potential as well as setting strategies in the development of the Muna Regency livestock sector. Internal factors and external factors found in Muna Regency indicate that for the availability of land for development of Bali cattle in Muna Regency has a rating value of 4 with a weight of 0.22 with a score of 0.89 , while for farms owned by the people of Muna Regency, in particular, is a privately owned business. For more details, presented in Table 5 
Table 5. Internal Factors Analysis of Bali Cattle Development in Muna Regency

\begin{tabular}{|c|c|c|c|c|}
\hline \multicolumn{2}{|c|}{$\begin{array}{l}\text { Internal and External Factors of Development of Bali } \\
\text { Cattle in Muna Regency }\end{array}$} & Weight & Rating & Score \\
\hline \multicolumn{5}{|c|}{ Internal Strength Factors } \\
\hline 1 & Land Availability for Development & 0.22 & 4 & 0.89 \\
\hline 2 & The Farmer's Experience Is Long Enough & 0.17 & 3 & 0.50 \\
\hline 3 & Private Owned Ranch Business & 0.22 & 4 & 0.89 \\
\hline 4 & $\begin{array}{l}\text { Bali Cattle Reproductive Performance Tends } \\
\text { to Be Good }\end{array}$ & 0.17 & 3 & 0.50 \\
\hline 5 & Availability of Bali Cow Seedlings & 0.22 & 4 & 0.89 \\
\hline \multicolumn{2}{|c|}{ Total Strength } & 1 & 18 & 3.67 \\
\hline \multicolumn{5}{|c|}{ Internal Weakness Factors } \\
\hline 1 & Requires large capital & 0.29 & 2 & 0.57 \\
\hline 2 & Packaging Results Processing Not Optimal & 0.29 & 2 & 0.57 \\
\hline 3 & $\begin{array}{l}\text { Lack of Application of Applicative Animal } \\
\text { Husbandry Technology }\end{array}$ & 0.14 & 1 & 0.14 \\
\hline 4 & $\begin{array}{l}\text { Institutional / Lack of Effectiveness of Animal } \\
\text { Groups }\end{array}$ & 0.14 & 1 & 0.14 \\
\hline 5 & Traditional Farms & 0.14 & 1 & 0.14 \\
\hline \multicolumn{2}{|c|}{ Total Weakness } & 1 & 7 & 1.57 \\
\hline \multicolumn{2}{|c|}{ strengths - weakness } & & & 2.10 \\
\hline
\end{tabular}

Source: Primary Analysis Results, 2019

Based on the data in Table 5 shows that internal factors in the development of Bali cattle in Muna Regency have different values, among others for weakness factors such as factors that require large capital weighing 0.29 , rating 2 with a score of 0,57 . Likewise, processing the results that have not been optimal to have the same value as the need for large capital. Meanwhile, for other internal factors in the form of Lack of Application of Applicative Animal Husbandry Technology, Institutional / Less Effective of Traditional Cattle and Livestock Groups has a weight of 0.14 , rating 1 , and a score of 0.14 . Accumulation scores from internal and external factors indicate the feasibility of beef cattle business in the Muna Regency. Based on the IFAS matrix, a value of 2.10 is obtained, which is derived from a strength factor score of 3.67 and a weakness factor score of 1.57. In the weight column, it is known that the weight of each factor is the result of questionnaire data processing. According to Rangkuti (2009), which is reinforced by Ikhsan and Artahnan (2011), the weight obtained by each factor is multiplied by 0.5 so that the total weight factor of strength and weakness is 1.00 .

Meanwhile, external factors show that the development of Bali cattle in the Muna Regency has a pretty good chance, especially the availability of forage fodder with a score of 0.73 as well as the presence of livestock extension workers have a score of 0.73 . Unlike the threat factors, especially livestock diseases and the lack of forage during the dry season with a score of 0.10 , this indicates that the people in Muna District lack experience in processing animal feed 
during the dry season. For more details, presented in Table 6

Table 6. Analysis of External Factors for Development of Bali Cattle in Muna Regency, 2019

\begin{tabular}{|c|c|c|c|c|}
\hline \multicolumn{2}{|c|}{$\begin{array}{l}\text { Internal and External Factors of Development of } \\
\text { Bali Cattle in Muna Regency }\end{array}$} & Weight & Rating & Score \\
\hline \multicolumn{5}{|c|}{ External Factors Opportunities } \\
\hline 1 & The existence of a financial institution & 0.14 & 3 & 0.41 \\
\hline 2 & Demand for livestock products is high & 0.09 & 2 & 0.18 \\
\hline 3 & Adequate Water Sources Available & 0.14 & 3 & 0.41 \\
\hline 4 & Source of Forage Eating Livestock & 0.18 & 4 & 0.73 \\
\hline 5 & Slaughterhouse availability (RPH) & 0.14 & 3 & 0.41 \\
\hline 6 & Government policy & 0.14 & 3 & 0.41 \\
\hline 7 & Animal Husbandry Extension & 0.18 & 4 & 0.73 \\
\hline \multicolumn{2}{|c|}{ Total Opportunities } & 1 & 22 & 3.27 \\
\hline \multicolumn{5}{|c|}{ External Threat Factors } \\
\hline 1 & Animal Disease & 0.10 & 1 & 0.10 \\
\hline 2 & Productive Slaughtering & 0.20 & 2 & 0.40 \\
\hline 3 & Livelihood Transition & 0.20 & 2 & 0.40 \\
\hline 4 & $\begin{array}{l}\text { Climate (Feed shortages during the dry } \\
\text { season) }\end{array}$ & 0.10 & 1 & 0.10 \\
\hline 5 & Absence of Livestock Price Standards & 0.20 & 2 & 0.40 \\
\hline 6 & Inadequate Transportation Facilities & 0.10 & 1 & 0.10 \\
\hline 7 & Livestock Theft Often Occurs & 0.10 & 1 & 0.10 \\
\hline \multicolumn{2}{|c|}{ Total Threats } & 1 & 10 & 1.60 \\
\hline \multicolumn{2}{|c|}{ Opportunities - Threats } & & & 1.67 \\
\hline
\end{tabular}

Source: Primary Analysis Results, 2019.

Analysis of Cattle Development Space in Muna District

Based on the matrix space analysis that the development area of the Muna district shows a positive trend value with a value $(1.57 ; 1.60)$. This indicates that the supporting factors of the development of animal husbandry areas supported by the area, the amount of feed, and the population of Bali cattle based on subdistricts can be calculated and analyzed according to the carrying capacity of the Muna district. According to Prayudha (2014), quadrant II shows that the region faces various threats, but still has strength so that the strategy adopted is to use the power to take advantage of long-term opportunities by implementing diversification strategies. Thus, the results of the space analysis corroborate the results of the external-internal matrix analysis. The third or final stage of strategy formulation (Rangkuti 2009) is the decision-making stage. This stage can be done using a SWOT analysis matrix. The results of the first and second stages of the analysis will be considered an input in formulating a SWOT analysis at this stage of decision making. For more details, analysis of the space of Bali cattle in Muna is presented in Figure 1. 


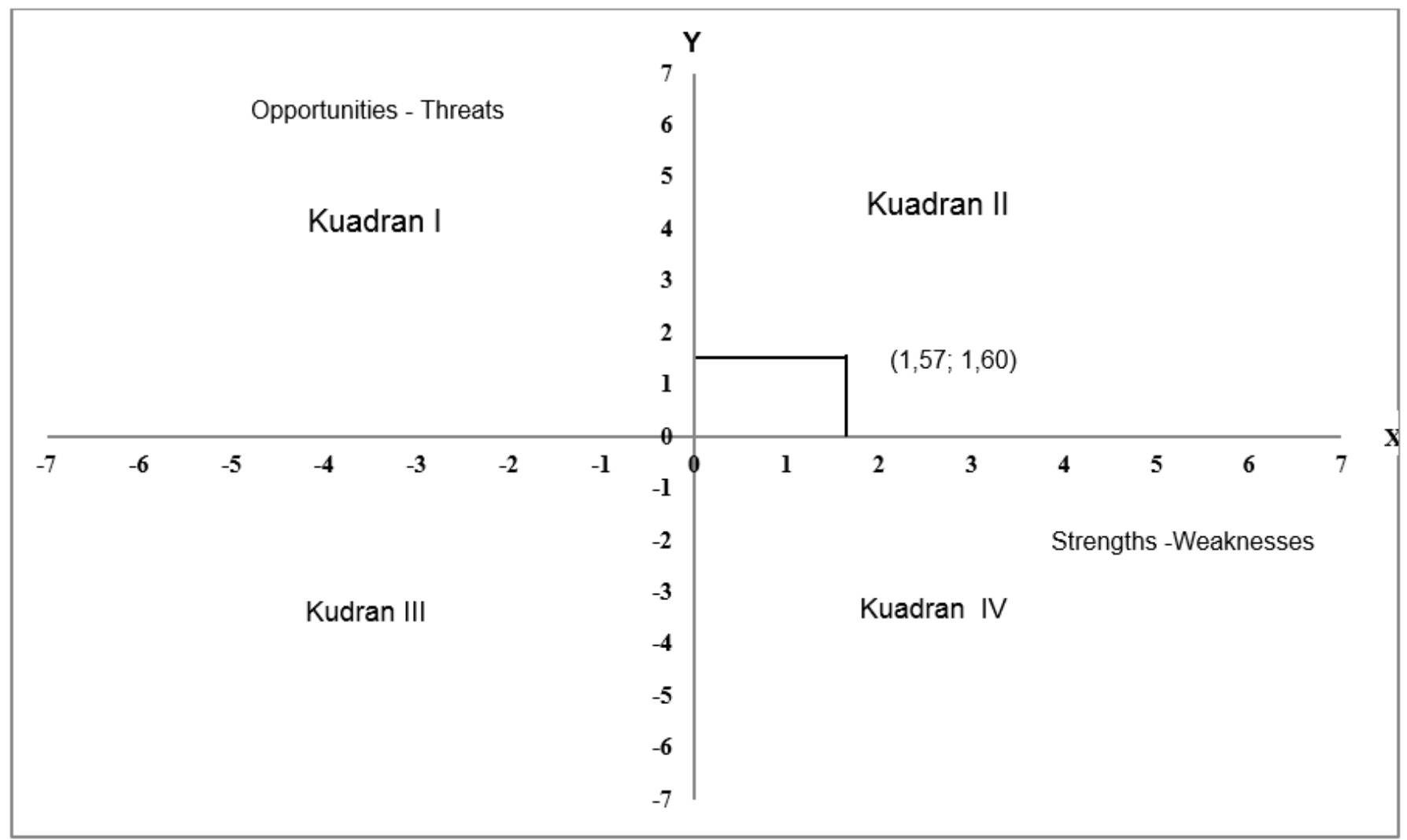

Figure 1 Results of Space Analysis of Bali Cattle Development Muna Regency, 2019.

\section{Bali Cattle Development Strategy in Muna District}

The formulation of the right strategy for a business can be done by monitoring the environment through environmental analysis techniques that can determine where the business position is, and what are the strengths, weaknesses, opportunities, and threats faced by Bali cattle farms in Muna Regency so that they can anticipate all problems. At the decisionmaking stage, the SWOT matrix needs to refer back to the IFAS matrix and the resulting EFAS matrix. Thus it can be seen the position of a business is in which cell of the Internal External matrix and which is in the quadrant of the space matrix (Marimin 2008).
The strategy to be used in the SWOT matrix uses the ST (Strengths-Threats) strategy as a strategy that utilizes all the power to eliminate the maximum threat to the development of Bali cattle farms in the Muna Regency. Strength and threat factors are reviewed and analyzed so that they can be formulated into strategies in the development of beef cattle breeding. At the same time, several strategies can be formulated by collaborating internal factors (strengths and weaknesses) and external factors (opportunities and threats). For this reason, a measurable and directed concept is needed to establish a strategy to develop the Bali cattle breeding business in Muna Regency. Development Strategy for Bali Cattle in Muna Regency is presented in Table 7. 
Table 7. SWOT Matrix Development of Bali cattle

\begin{tabular}{|c|c|c|}
\hline Internal Factors & $\begin{array}{l}\text { Strengths (S) } \\
\text { 1. Availability of Land for } \\
\text { Development } \\
\text { 2. Farmers' experience is quite long } \\
\text { 3. Private Owned Farm Business } \\
\text { 4. Availability of Bali Cow Seedlings }\end{array}$ & $\begin{array}{l}\text { Weakness (W) } \\
\text { 1. Requires Large Capital } \\
\text { 2. Packaging Results Processing Not Optimal } \\
\text { 3. Lack of Application of Applicative Animal } \\
\text { Husbandry Technology } \\
\text { 4. Institutional / ineffective Livestock Group } \\
\text { 5. Traditional Farms }\end{array}$ \\
\hline $\begin{array}{l}\text { Opportunity (O) } \\
\text { 1. The existence of a financial } \\
\text { institution } \\
\text { 2. Demand for livestock } \\
\text { products is high } \\
\text { 3. Adequate Water Sources } \\
\text { Are Available } \\
\text { 4. Forage Sources for Feeding } \\
\text { Livestock } \\
\text { 5. Availability of Abattoirs } \\
\text { (RPH) } \\
\text { 6. Government Policy } \\
\text { 7. Animal Husbandry } \\
\text { Extension }\end{array}$ & $\begin{array}{l}\text { Strategic S-O } \\
\text { 1. Increasing the identification of } \\
\text { land use as Bali cattle logging areas } \\
\text { 2. Training on the development of } \\
\text { Bali cattle for breeders } \\
\text { 3. Make regulations on institutions in } \\
\text { the context of livestock ownership } \\
\text { 4. Provision of Bali seeds in good } \\
\text { condition }\end{array}$ & $\begin{array}{l}\text { Strategic W-O } \\
\text { 1. Provision of credit to support the livestock } \\
\text { business } \\
\text { 2. Training the application of appropriate } \\
\text { technology to support consumer demand } \\
\text { 3. Reactivating livestock institutions to } \\
\text { accommodate farmers' problems } \\
\text { 4. Increasing the capacity of breeders in the } \\
\text { management of traditional farms }\end{array}$ \\
\hline $\begin{array}{l}\text { Threat (T) } \\
\text { 1. Livestock Disease } \\
\text { 2. Productive Animal Cutting } \\
\text { 3. Livelihoods Transition } \\
\text { 4. Climate (Feed shortages } \\
\text { during the dry season) } \\
\text { 5. Lack of Standard Animal } \\
\text { Prices } \\
\text { 6. Inadequate means of } \\
\text { transportation } \\
\text { 7. Livestock Theft Often } \\
\text { Occurs }\end{array}$ & \begin{tabular}{|l} 
Strategic S-T \\
1. \\
$\begin{array}{l}\text { Procurement of veterinarians and } \\
\text { optimizing the performance of } \\
\text { animal husbandry extension }\end{array}$ \\
workers \\
2. The sanctioning slaughter of \\
productive livestock \\
3. Addition or provision of \\
productive cattle breeds \\
Making roads to facilitate access to \\
transportation in the context of \\
increasing people's purchasing \\
power \\
Improving the security system by \\
cooperating between the breeder \\
community and the security forces
\end{tabular} & $\begin{array}{l}\text { Strategic W-T } \\
\text { 1. Adding farm extension workers } \\
\text { 2. Improvement of livestock business } \\
\text { governance } \\
\text { 3. Opening job opportunities for beef cattle } \\
\text { farming in the development center area } \\
\text { 4. Training in animal feed processing } \\
\text { technology } \\
\text { 5. Doing the night watch at a dangerous point } \\
\text { for cattle theft }\end{array}$ \\
\hline
\end{tabular}

Source: Matrix Swot Analysis of Bali Cattle Development In Muna District

\section{IV.CONCLUSION}

LQ analysis results show that the Muna Regency has several sub-districts, including the Districts of Tongkuno, South Tongkuno, Parigi, Kabangka, Watopute, Napabalano, and Lasalepa which have the potential to develop Bali cattle. SWOT analysis, where one of the strongest factors that have the highest score is the availability of land for development, privately owned animal husbandry, and the availability of Bali cattle with a score of 0.89 . As for the weakness factor of the development of the Bali cattle breeding center area is the lack of application of applicable livestock technology, institutional/ineffective traditional livestock and livestock groups with a score of 0.14 . Then for the opportunity factor, several items can be used as a 
support in the development of the livestock sector in Muna Regency, including forage sources for livestock with a score of 0.73 . Capacity analysis carried out while synergizing with L / Q analysis indicates that for Tongkuno District has a total capacity of 42 tails, South Tongkuno 0 tails, Parigi 5,016 tails, Kabangka 2,198 tails, Watopute 917 tails, Napabalano 206 tails, Lasalepa 0 tails, and Maligano 2,486 tails.

\section{REFERENCES}

[1]. Abadi. M, Surahmanto, Rizal. A Nasiu.F, Fatmawati. 2019. Carrying Capacity of Forage as Cow and Goat Feed in West Muna Regency, Southeast Sulawesi Province. Animal Husbandry Bulletin 43 (3): 151-157, August 2019. Faculty of Animal Science, Halu Oleo University, Kendari.

[2]. Bamualim, A. B. Tiesnamurti and Chalid Talib. 2008. Indonesian Livestock Production. Presented at the National Seminar on Animal Husbandry and Veterinary. August 3007. Animal Husbandry Research Center. Ministry of Agriculture's R\&D Agency.

[3]. David, 2006. Strategic Management, Ed.7. PT. Index. Jakarta.

[4]. Hidayati. 2009. Cattle Fattening Business in Local Economic Development Efforts in Ngemplak Asam Hamlet, Umbulmartani, Ngemplak, Sleman, Yogyakarta. Thesis. Department of Community Development. Yogyakarta.

[5]. Ikhsan, S., \& A. Artahnan. 2011. SWOT analysis to formulate the Muna Regency commodity development strategy in Figures 2019. Area and Population of Bali Cattle in Muna Regency, 2019.

[6]. Marimin, 2008. Compound Criteria and Decision Making Techniques and Applications. PT. Gramedia Widiasarana Indonesia, Jakarta.

[7]. Nafiu Ld, Saili T, I AS, Karim J, Abadi M. 2017. BluePrint of Animal Husbandry in South Konawe District, Cooperation of Animal
Husbandry and Animal Health Service in South Konawe District. Kendari.

[8]. Nugroho, B.A. 2006. Development of Animal Husbandry Agribusiness Development Pattern of Productive Economic Assistance (Study in North Sulawesi Province). p. 162-172. In B. Suryanto, Isbandi, B.S. Mulayatno, B. Sukamto, E.Rianto, and A.M. Legowo Empowerment of Animal Husbandry Society in the Field of Agribusiness to Support Food Security. Proceedings of the 2006 National Seminar, Semarang. Diponegoro University. Cut (Case Study of Kesum Village, Namo Rambe Village, Deli Serdang Regency). Thesis. Faculty of Agriculture, University of North Sumatra, Medan.

[9]. Pambudy, R and Sofyan Sudardjat D. 2000. Towards the Two Century History of Indonesian Animal Husbandry and Health; Care for Smallholder Farmers, Agroindo Mandiri Foundation. Jakarta.

[10]. Parakkasi, A. 1999. Ruminant Nutrition and Animal Feed. Universitas Indonesia Press, Jakarta.

[11]. Prayudha, E. D., S. Bambang \& H. Boedi. 2014. Sustainable Coast Group Strategy in the Development of Mangrove Rehabilitation in Karangsong Village, Indramayu Regency. Diponegoro Journal of Maquares Management of Aquatic Resources. 3: 8087.

[12]. Rangkuti, F. 2009. SWOT Analysis, Techniques for Dissecting Business Cases. PT. Gramedia Pustaka Utama, Jakarta.

[13]. Rangkuti. F, 2006. SWOT Analysis of Techniques for Dissecting Business Cases. Reorienting the Concept of Strategic Planning to face the 21st Century. PT Gramedia Pustaka Utama, Jakarta.

[14]. Saili T, Nafiu Ld, Baa Ld, Rahadi.S, Napirah. A Sura I. W, Lopulalan.F. 2017. Effectiveness of Estrus Synchronization and Spermatozoa Fertility Results of Sexing in Bali Cattle in Southeast Sulawesi. Faculty of Animal 
Husbandry, Halu Oleo University in collaboration with the Regional Technical Implementation Unit of Animal Husbandry, Department of Agriculture and Animal Husbandry of Southeast Sulawesi. Veterinary Journal September 2017 Vol. 18 No. 3: 1-7 ISSN: 1411-8327; eISSN: 2477-5665 DOI: 10.19087 / j veterinary.2017.18.3.

[15]. Santosa, U., 1995. Management of Beef Cattle Maintenance. Self-Publisher Issuer. Jakarta.

[16]. Sumanto and E. Juarini. 2004. Guidelines for Identifying Regional Potential and Implementation. The collaboration of the Bogor Central Animal Husbandry and Animal Husbandry Development Division.

\section{Cite this article as :}

Muhammad Amrullah Pagala, Deki Zulkarnain, Hidayat, La Ode Munadi, "Potential Development of Bali Cattle in Muna Regency in Efforts to Support National Meat Self-Sufficiency", International Journal of Scientific Research in Science, Engineering and Technology (IJSRSET), Online ISSN : 2394-4099, Print ISSN : 2395-1990, Volume 7 Issue 1, pp. , January-February 2020. Available at doi : https://doi.org/10.32628/IJSRSET207130 Journal URL : http://ijsrset.com/IJSRSET207130 